\title{
Curating Gothic Nightmares
}

\section{Heather Tilley}

Gothic Nightmares: Fuseli, Blake, and the Romantic Imagination was a major exhibition held at Tate Britain in 2006, exploring the work of the leading artists Henry Fuseli and William Blake, as well as the comic caricaturist James Gillray, in the context of the Gothic - the 'taste for fantastic and supernatural themes which dominated British culture from around 1770 to 1830 '. ${ }^{1}$ This review takes the occasion of a workshop given by the show's curator, Martin Myrone, at the conference The Verbal and the Visual in Nineteenth-Century Culture, held at Birkbeck in June 2006, as a starting point to reflect on the practice of curating, and its relation to questions of the verbal and the visual in contemporary art historical practice.

The first section of this review draws on Myrone's own account of the different roles played by texts and images in the curation of the exhibition, at both its inception and design stages. Very much a visual spectacle in itself, the exhibition prompted an explicit engagement with questions of the genre of Gothic, through a dramatic display of the differences between 'the Gothic' in literature and 'the Gothic' in the visual arts within eighteenth- and early nineteenth-century culture. The exhibition reflected on the way in which the Gothic slipped in and out of 'high' and 'low' cultural forms and institutions, something especially evident in the attention given at the exhibition to Fuseli's The Nightmare (1782). The second section of this review addresses more closely how this tension manifests itself in our own contemporary culture, signalling the various ways in which the 'Gothic' was interpreted and reinscribed by visitors, especially those who dressed up for the exhibition. This reminds us that the Gothic is not just an academic or curatorial category: insofar as any exhibition space also brings to visibility the "body of the public", Gothic Nightmares blurred the distinction between subject and object, then and now. Finally, the workshop at Birkbeck itself was part of a range of extra events and texts that shaped, and continue to shape, the cultural effect of the exhibition. The last section of this review addresses the exhibition's 'marginalia' (specifically the catalogue), drawing parallels with Catherine Flood's discussion in 
this issue of 19 of the function of the catalogue in nineteenth-century exhibition viewing experiences.

\section{I}

The Curator's Exhibition

As part of the conference workshop, Martin Myrone circulated various documents relating to the show: a draft proposal of the show, a press release in the form of a room guide, and a link to the exhibition's webpage on the Tate Britain website. The material also outlined some of the significant critical studies on the themes of Gothic horror and fantasy, both in cultural commentary and literary studies. ${ }^{2}$ The two broad objectives of the exhibition were (1) to situate Fuseli's work (in particular The Nightmare) within current debates on the nature and genre of the Gothic, whilst questioning the distinction between the Gothic in the literary and visual imagination of the period, and (2) to build a show that would have a wide public appeal to a nonspecialist audience. More specific curatorial aims were to reflect on the differences between academic disciplines and museums and galleries in the treatment of subjects such as 'the Gothic'; to set forward a reappraisal of the visual art of 17701830; and to explore the nature of spectacle in art and culture in both the Romantic period and in contemporary culture.

The workshop itself took the format of a slideshow walking through the exhibition, with Myrone commenting on specific issues or areas of interest that emerged from each of the nine rooms in the exhibition: (1) The Nightmare: Fuseli and the Art of Horror; (2) Perverse Classicism; (3) Superheroes; (4) Gothic Gloomth; (5) The Phantasmagoria; (6) Witches and Apparitions; (7) Fairies and Fatal Women; (8) Revolution, Revelation and Apocalypse; (9) The Nightmare in Modern Culture. Through this virtual tour, participants were channelled through the space without the ordinary distractions, divergences and traffic problems associated with a major exhibition. Although the exhibition did not argue for a firm exchange of ideas between the writers and visual artists of the period, it did suggest the different ways in which the verbal and visual nature of the Gothic may have affected eighteenth- and early nineteenth-century spectators and/or readers. Further, the exhibition aimed to recreate that experience for the twenty-first-century spectator 
through attention to the staging of the paintings and the distribution of reading material throughout the rooms.

By introducing the moving image, with the installation of the phantasmagoria in room five and examples from cinema in the final room, 'The Nightmare in Modern Culture', 3 the exhibition drew further parallels between eighteenth-century and contemporary visual culture. Located at the exhibition's centre, the phantasmagoria is crucial in rethinking late eighteenth-century visual culture as straddling across conventional genres of art history, as well as being in obvious dialogue with the cinematic excerpts in the last room. Together, they emphasised the experience of the visual in both cultures as kinetic, dependent upon the interaction of the spectator's body with the viewing space and drawing attention to the exhibition itself as spectacle. As well as staging a separate event, Gothic Nightmares: Focus on Film, and showing a selection of classic Gothic films (some curated by Mark Kermode) as part of the exhibition's wider events programme, the design of the exhibition was also inspired by Dario Argento's horror film Suspiria (1977), for example through the use of intensely coloured walls and free floating drapes.

The introduction of cinematic content was quite an innovative step for Tate Britain and demonstrated the show's curatorial resonances with contemporary art exhibitions, as well as more traditional art historical shows. Although it was followed by a blockbuster on another key Romantic painter, John Constable, ${ }^{4}$ Gothic Nightmares' engagement with issues of contemporary spectatorship and visual culture echoes unexpectedly with more recent events, such as Antony Gormley's show at the Hayward, Blind Light (2007). Gormley's 'Blind Light' installation, a cloud-filled glass box, was a highly reflexive mediation of the nature of vision and the experience of contemporary visual culture, as inside the installation viewers, as subjects of vision, became blind to their immediate surroundings whilst acting as moving, shadowy objects of vision to those viewers outside the exhibit. Mediating on the interaction of the body with the conditions of the interior space it inhabits, Gormley's installation echoes and tonally reverses the experience of the phantasmagoria. Both act as spaces that disturb the spectator's consciousness of their own body as an object within the exhibit and the orientation of other bodies in the space.

Heather Tilley, Curating Gothic Nightmares

19: Interdisciplinary Studies in the Long Nineteenth Century, 5 (2007) www.19.bbk.ac.uk 
Capturing the shifts between the spectator's experience of exterior and interior space was a fundamental dynamic of Gothic Nightmares, which was designed to encourage reflection on the difference between the staged spectacle of the Gothic (as demonstrated by the visual art) and the more intimate encounter with the Gothic to be had in reading Gothic literature. The staging and structure of the exhibition emphasised these different effects, as the use of colour, space and texture were deliberately chosen to create alternative sensations of theatricality, communality, and intimacy.

Two examples epitomise these effects. The viewer's first encounter in the exhibition was with Fuseli's The Nightmare, hung against dark red walls and dramatically lit with spot lighting. While very different from its original exhibition conditions, ${ }^{5}$ the curatorial design encapsulated the way in which Fuseli's image has entered the cultural imagination in often very bold and dramatic ways. Following its exhibition to the public in 1782, it quickly gained iconic status, establishing Fuseli as a major figure in the artistic circles of the day as a creator of outrageous, shocking and erotic themes. Its graphic exploration of horror, folklore, and concepts of the imagination and grotesque sexuality link it to the genre of the Gothic, a key facet of the Romantic imagination. By deploying this painting in such a dramatic way as its starting point, the exhibition confirmed The Nightmare's status as a key image, both within Fuseli's career and in Romantic visual culture more generally. The bold and spectacular nature of the painting's display also quickly established that the exhibition would be asking new questions and opening new terms of debate concerning the history of exhibiting Fuseli, not least how he has traditionally been set apart from his contemporaries (thus inspiring a debate over the very nature of the term 'Romantic'). By directing the viewers to hold this image in mind as they navigated the exhibition space, curatorial choices encouraged them to establish a relationship between this painting and the material in the following rooms, making the question of what Fuseli was doing in this painting central to the experience of the show.

Spatial design was also used to contrast the ideas of the Gothic as a visual and as a verbal form. The fourth room, 'Gothic Gloomth', which explored most explicitly the experience of Gothic as a textual medium, created a very different effect from the first room. Walls were painted blue to create a greater sense of 
enclosure, suggestive of the idea that reading literature enabled a more intimate encounter with the Gothic. The extracts gathered in this room were dramatically staged, on prop books chained down to a central plinth. Here then, the curatorial desire was to articulate a reflection on the Gothic both as a visual spectacle and as a read experience, allowing for a remediation of the verbal and visual dynamics within the medium of the exhibition space. Throughout the exhibition, textual information accompanying the images was kept to a minimum, in order to keep the focus of the visitor's attention on the art objects themselves. Occasionally, if a passage from a contemporary text related to an exhibit, that passage was displayed in a caption. The collection of captions and texts in a book placed on a pedestal in the corner of every room further suggested the different dynamics of reading and viewing.

The shared ownership of the Gothic formed a central part of the workshop discussion. The distances and differences between a subject's life in academic disciplines and in museums and galleries were explored at length, as the term 'Gothic' is situated at the intersection of academia and the museum. Although literary and cultural historians have re-appraised Gothic literature in its political, social and psychological contexts, there has been, as of yet, limited crossover of these themes into discussions of the visual art of the period exploring the Gothic. The exhibition, and its accompanying catalogue with critical essays by Christopher Frayling, Marina Warner and Myrone himself, offers a constructive dialogue between the fields of literary studies and art history. ${ }^{6}$ As we will see, however, the space of the exhibition and its interpretation by viewers was potentially in conflict with the critical objectives of the curators, not least because those objectives might be diluted by the wide popular appeal of featured artists such as Fuseli, Blake, Gillray, and George Romney in their reworking of the aesthetics of the sublime and exploration of the themes of horror and fantasy - an obvious sensational attraction. This potential conflict was recognised at the outset, with the exhibition design playing to these expectations by incorporating spectacle and sensation into the fabric of the exhibition's design itself, while still addressing 'challenging' topics around the nature of sexuality and identity to a wide and, in the main, unspecialised audience. $^{7}$

Overall, Myrone commented on how walking through the exhibition was a profoundly artificial experience, having nothing to do with the nature of late- 
eighteenth-century experience of art. (His playful approach is exemplified, for instance, by the ironic use of pink for the walls of the 'Superheroes' room.) Instead, the design sought to encapsulate the wider cultural connotations of the Romantic imagination. In this way, the exhibition space conflated and distorted the exteriority of the eighteenth-century Gothic in art, presenting it as a spatial aesthetic when, in reality, these images would have been jostling with a range of other genres and images in the mixed, free-for-all spaces of the eighteenth-century salons.

In a sense, the challenges of recreating Gothic spaces within the pre-existing architecture of the Tate's exhibition space actually allowed for creative engagement with the themes of the exhibition itself, such as the engagement of the Gothic with themes of revolution. The architecture dictated the show's narrative flow: as well as dramatically bringing attention to the theatricality of the Gothic in visual form (for example illustrations of scenes from Milton and Shakespeare), walking through the rooms also gave a sense of the reading process.

II

\section{The Goth’s Exhibition}

The exhibition made visible how the Gothic is not just a historical category; it has a vibrant subculture of its own, which on occasion turned the exhibition into a performative space. Significantly, many exhibition goers regarded the exhibition as a space in which they too could act as displays, inviting and provoking visual comparisons between their own body and dress and the art objects on display. The late eighteenth-century exhibition space has itself been documented as a place where to be seen and to look at one another was as important, if not more important, than looking at pictures. ${ }^{8}$ The desire of exhibition goers both to restage and reinterpret eighteenth-century Gothic culture emphasises the ways in which the idea of 'the Gothic' has been kept alive and transformed in contemporary popular culture, perhaps unique amongst cultural trends. Twenty-first century Gothic culture is disseminated across a heterogeneous range of spaces, straddling not only the visual arts and literature, but also the fashion, cosmetics and music industries, clubs, celebrity culture, and even the urban landscape, with areas like Camden in London synonymous with contemporary Goth culture, and also associated with other 
subcultures such as punk. 'Gothic' today signals a resistance to commercialised, branded fashion and to dominant paradigms of both the masculine and feminine body.

However, over the past few years, Gothic has also become a high-end fashion style. Recent collections by designers such as Vivienne Westwood and John Galliano demonstrate the shared space that 'alternative' and 'mainstream' cultures occupy in their referencing and recycling of the Gothic. Whilst this is in part symptomatic of haute couture fashion designers drawing increasingly upon subcultures (particularly from music) in their collections, it also demonstrates an important point about the ambivalent cultural positioning of the Gothic between high and low art. The Gothic's mainstream position can also be seen in the immense popularity of TV shows such as Buffy the Vampire Slayer (which was on sale in the Tate shop during the exhibition). The Gothic can signify a range of fundamental questions and themes about the relationship between the human and the supernatural, death and the macabre, which resist dominant homogenising cultural ideologies, while also acting as little more than an aesthetic marker, as this resistance becomes itself marketed to mass audiences (for example, Buffy fans), or wealthy elites (in the case of haute couture). However, even those instances where the Gothic enters into the mainstream reveal the complex workings of the genre, as Sarah Michelle Gellar's portrayal of Buffy did initially offer a reversal of many feminine stereotypes to a mass audience (it was not so much the show as the media's fixation on Gellar's celebrity which perhaps diluted Buffy's initial edginess).

The arbitrary nature of the Gothic genre is drawn out in both the Gothic Nightmares show and the exhibition catalogue. In the exhibition itself, the ambivalence of this shared space was materialised in the room devoted to 'Fairies and Fatal Women', with a curtain dividing oil paintings of fairies from pornographic drawings by Fuseli and Theodor von Holst. This division captured the images' sense of private titillation, especially given the curtain's unexpectedly semi-transparent nature, although this reflection on the still-transgressive nature of pornography actually became quite a kitsch feature of the exhibition. Again, the space itself was charged and transformed by the ambivalent nature of the Gothic. This room then physically demonstrated Myrone's claim that 'the art of Fuseli and his contemporaries can be absurd, even laughable, and pretentious in the extreme' and 
that it is therefore perhaps 'all the more valuable historically ... potentially exposing, rather than helping to mask, the fatal emptiness at the heart of bourgeois modernity'. 9 Mrone further explores the relationship between the genres of contemporary pornography and horror and the eighteenth-century Gothic through Linda Williams' category of 'body genres' and asks whether 'the inscriptions on Fuseli's dodgiest drawings are just a veil of pretension':

What if such designs were literal aids to masturbation, rather than 'erotic' explorations of some profound or dark dimension of humanity? Is it possible to imagine that they could be both? Can art history bear to apprehend the possibility of actual physical arousal? Or outright disgust? ${ }^{10}$

The encounter between eighteenth-century and twenty-first-century Gothic further opens up this association of 'the Gothic' with the subversive. In the gallery space, the genre's subversiveness was effected through the destabilisation of historical boundaries, as the desire to reinscribe the exhibition space along contemporary Gothic lines resisted the overall historicising aims of the exhibition itself. As Catherine Flood demonstrates in this issue of 19, there can be divergence between what we might learn from an exhibition catalogue and other material and sources that re-enact the experience of the exhibition. New technologies present to us, as critics and historians, a fuller range of sources (and indeed voices) around the edges of events such as the Gothic Nightmares exhibition, revealing also an expanded notion of what is at stake in curating a major exhibition. For example an MP3 recording of an educational workshop, one of the range of activities run by Tate Britain around the exhibition and initially broadcast on the independent radio station Resonance FM, offers an (edited) range of reflections from young Goths on what the historical 'Gothic' means to them, intercut with samples of another important strand of contemporary Goth culture, music. The workshop also provided a forum for these teenagers to discuss and share experiences of Gothic culture today, demonstrating the ways in which twenty-first- and eighteenth-century Gothic meet within the wider exhibition space, reaching out and transforming each other dynamically in the process. ${ }^{11}$

III

Gothic Nightmares: Text, Image, Event

Heather Tilley, Curating Gothic Nightmares

19: Interdisciplinary Studies in the Long Nineteenth Century, 5 (2007) www.19.bbk.ac.uk 
The Gothic Nightmares exhibition was not simply confined to the space of the gallery rooms, as the above example demonstrates. A series of events, talks and workshops inspired by the subject of the exhibition were set up alongside the exhibition itself, including a workshop with the graphic novelist Alan Moore on Fuseli and comic book culture, fairytale reading sessions, and a Goth party hosted by the Tate, which included projections of mice creeping along the walls of the exhibition. During the period of the exhibition, the show's sensational feel was conveyed through the striking publicity material, which reproduced Fuseli's Nightmare and depicted a close-up of the imp perching on the woman's torso, focusing on her ambivalent pose of abandonment. Indeed, the image produced a similar effect within its own original exhibition environment. Frayling's essay in the exhibition catalogue documents the impact of Fuseli's painting in its immediate context. On Thursday 9 May 1782, the day after it was reviewed in the Morning Herald, 2,713 people were recorded as visiting the Academy exhibition - the highest figure for a single day of the entire run (apart from the last) - the average so far in 1782 had been 1,962 people a day. Exhibition goers were perhaps attracted by the review's promise of the wildness and 'disagreeable' subject matter of Fuseli's painting. ${ }^{12}$ Gothic Nightmares's supporting textual material retained the exhibition's playful, theatrical construction of the Gothic, with the website dramatically introducing featured artists as the 'cast of characters'. This final section explores the way in which the show reached out from the walls of the gallery through the medium of text, offering some broad reflections on the role of the exhibition catalogue in this process.

In this issue of 19, Catherine Flood draws out the play between the verbal form of the catalogue and visual experience of the art objects in various nineteenthcentury accounts, noting the way in which they are marked by (and indeed encourage) an extra spatial and bodily performance within the exhibition space. This invites us, broadly, to think about the changing social function of the exhibition catalogue, as well as the tensions and ellipses between the spectacle of the exhibition space and the marginalia around it. The relation between guides, captions, catalogues and the viewing experience of Gothic Nightmares loosely demonstrates that the function of these guides and catalogues no longer represents an attempt to 
restrict and manipulate the interpretation of space and image, but rather to encourage reflection on the very act of being a spectator within the specific context of the gallery. Flood's essay explores in detail the presence of the nineteenth-century catalogue within the gallery and the complex ways in which the catalogue used institutional authority to direct the viewer whilst in the exhibition space. ${ }^{13}$ By contrast, the late twentieth-century and twenty-first-century catalogue might be thought of as an object that confers authority on the exhibition space from outside the walls of the gallery itself.

Within the more static space of the book, the Gothic Nightmares catalogue extends the play between the visual and verbal experience of the Gothic by interlacing the index of images with quotations from textual sources: contemporary letters, documents and literary texts, as well as historical literary texts that acted as source material for the artists (for example, Milton, Shakespeare, and the Bible). The catalogue also retains the exhibition's sense of playfulness, in one instance drawing parallels between accusations of Fuseli's painting Percival Delivering Belisane from the Enchantment of Urma (1783) as base and juvenile and the Gothic paintings discovered in Saddam Hussein's private quarters, which were taken 'as evidence of that dictator's moral and aesthetic depravity'. ${ }^{14}$

In today's exhibitionary complex, the catalogue has an important relationship with the memory of the exhibition. Flood briefly touches upon the way in which annotating catalogues in the nineteenth century acted as an 'aid to memory', arguing that the catalogue was 'part of the exhibition that you purchased and carried away with you', thus acting as 'cultural capital' ${ }^{15}$ However, also notable is her example of the 1878 Times editorial which exhorts Royal Academy visitors to study the catalogue before visiting the exhibition. ${ }^{16}$ In today's exhibition market, exhibition exits are usually located next to a shop or retail stall; thus viewers are immediately encouraged to invest in the catalogue upon leaving the exhibition (often priced at three to four times the cost of a ticket). The social meaning of the exhibition catalogue has shifted; it offers an opportunity to engage with the critical debates around the subject by reading the critical essays at the front of catalogues, whilst also becoming a valuable object in its own right. The exhibition catalogue signals not so much an attempt to dictate the viewer's circulation through the exhibition space, than an appeal to the viewer's desire to retain a memento of the 
show (through the catalogue, they can own coloured reproductions of all the objects featured). It is also a way for the institutions staging the exhibition to generate further income. Further, its main relationship is no longer with the space of the exhibition itself, but rather with the afterlife of the exhibition.

In this instance, the catalogue re-emphasises the verbal and visual dynamics of the Gothic genre articulated within the walls of the exhibition space. It further strengthens the art historical claims of the show and fulfils Myrone's desire to present a fresh look at the visual culture in which Fuseli's Nightmare emerged and the visions and nightmares it inspired. It functions as a useful document of the show, which as an event is spread over a range of spaces and institutions and shaped by a wide number of participants, such as academics, historians, listeners, discussants, spectators, and performers. The catalogue has also become an object of desire in itself; selling out its entire print run, its value has increased sharply, indicative of the popularity and glamour of its subject, which continues to fascinate its still-diverse audiences.

\section{Endnotes:}

\footnotetext{
${ }^{1}$ Exhibition abstract, taken from Tate Britain website, $<$ Hhttp://www.tate.org.uk/britain/exhibitions/gothicnightmares/H> last accessed 14 August 2007.

${ }^{2}$ For example, Christopher Frayling, Nightmare: The Birth of Horror (London: BBC, 1996), and in literary studies James Watt, Contesting the Gothic: Fiction, Genre and Cultural Conflict, 1764-1832 (Cambridge: Cambridge University Press, 1999).

3 This final section of the exhibition explored the 'artistic progeny' of Fuseli's The Nightmare which, as Frayling and Myrone note, 'are legion'. The image continued to be reproduced and circulated in a variety of forms and mediums well into the nineteenth century, from the radical caricatures initially published by Thomas Rowlandson (1784) and James Gilray, to Parisian book illustrations of the 1820s and 1830s. Frayling and Myrone also point out the image's fusion with the mythology of the vampire, as well as its entry into early film production as a way of organising the visual image within the frame (for example in Robert Wiene’s The Cabinet of Doctor Caligari [1919]). As they argue 'film references - from German Expressionism to Hollywood horror to recent costume dramas - have “democratised” Fuseli's most famous painting to the point where it has long since moved beyond visual cliché' (207).
} 
${ }^{4}$ Constable: The Great Landscapes, the central feature of which was gathering together for the first time all of John Constable's seminal six-foot exhibition canvases, including the famous paintings The Hay Wain (1820-21) and The White Horse (1819).

${ }^{5}$ Christopher Frayling's analysis of the 1782 RA exhibition, where Fuseli's Nightmare was first exhibited, restores the sense of original viewing practices to these paintings. He discusses several images of late eighteenth-century exhibition goers, which demonstrate the competition paintings faced with other paintings, often stacked high up the walls and outside of viewers' lines of vision (as witnessed in Johann Heinrich Ramberg's engraving Exhibition of the Royal Academy, 1787, published by A. C. de Poggi in 1787); and even from the exhibition viewers themselves: 'the fashionably dressed visitors, a sample of London high society, are indeed "gazing at each other" rather than at the paintings' (Christopher Frayling, 'Fuseli's The Nightmare: Somewhere between the Sublime and the Ridiculous', in Gothic Nightmares: Fuseli, Blake, and the Romantic Imagination ed. by Martin Myrone [London: Tate Publishing, 2006], pp. 9-22 [p. 9]).

${ }^{6}$ Tate simultaneously published an accompanying Gothic critical reader, divided into five sections covering 'The Gothic: A Sampling of Some Key Texts and Images': 'The Psychological and Aesthetic Functions of Horror and the Fantastic'; 'Rediscovering the Gothic'; 'Fantastic Artists and Writers'; 'Moral Panics and Critical Debate: Opposition to Gothic Horror and Fantasy'. It includes extracts from and samples of key Gothic texts and images (among them passages from Horace Walpole's The Castle of Otranto [1764], Ann Radcliffe's The Mysteries of Udolpho [1794], Percy Bysshe Shelley's Ghasta or, the Avenging Demon!!! [c.1809-10], Bram Stoker’s Dracula [1897]), as well as extracts from significant political and aesthetic treatises which helped to shape the cultural context in which the Gothic emerged (for example Joseph Addison's and Edmund Burke's writings), and responses to aspects of the Gothic (for example Freud's The Uncanny [1919]). The Gothic Reader: A Critical Anthology ed. by Martine Myrone and Christopher Frayling [London: Tate Publishing, 2006]).

${ }^{7}$ Myrone provided statistics outlining that only an average of $20 \%$ of visitors at any exhibition has specialist art historical knowledge.

${ }^{8}$ See Tony Bennett’s ‘The Exhibitionary Complex’, New Formations 4 (1988), and Suzanne Matheson, “'A Shilling Well Laid Out”: the Royal Academy's Early Public', in Art on the Line: The Royal Academy Exhibitions at Somerset House 1780-1836, ed. David Solkin (New Haven: Yale University Press, 2001), pp. 39-53.

${ }^{9}$ Martin Myrone, 'Fuseli to Frankenstein: The Visual Arts in the Context of the Gothic', in Myrone, ed., (2006), pp.30-40, p.39.

${ }^{10}$ Myrone (2006), p.38

${ }^{11}$ An MP3 of this workshop can be found on the Tate website $<$ http://www.tate.org.uk/youngtate/project_files/project_gothicround.htm>, [accessed 14 August 2007]

${ }^{12}$ Review quoted by Frayling, in Myrone, ed., (2006), pp.10-11. 
${ }^{13}$ Catherine Flood, “ “And Wot does the Catlog tell me?”: Some social meanings of NineteenthCentury Catalogues and Gallery Guides', 19: Interdisciplinary Studies in the Long NineteenthCentury 5 (2007) <Hwww.19.bbk.ac.ukH>, 7-8.

${ }^{14}$ Myrone, ed., (2006), p.85.

${ }^{15}$ Flood (2007), 15-6.

${ }^{16}$ Flood (2007), 4-5. 